\title{
A TRANSCENDÊNCIA DO EGO
}

\section{Esboço de uma descrição fenomenológica}

Jean-Paul Sartre

Para a maior parte dos filósofos, o Ego é um "habitante" da consciência. Alguns afirmam a sua presença formal no seio das Erlebnisse como um princípio vazio de unificação. Outros psicólogos, na maior parte, pensam descobrir a sua presença material, como centro dos desejos e dos atos, em cadä momento da nossa vida psíquica. Nós queremos mostrar aqui que o Ego não está na consciência nem formal nem materialmente: ele está fora, no mundo; é um ser do mundo, tal como o Ego de outrem.

\section{I}

\section{EU E MIM}

\section{A) TEORIA DA PRESENÇA FORMAL DO EU}

Devemos concordar com Kant que "o Eu Penso deve poder acompanhar todas as nossas representações". Mas devèmos concluir daí que um Eu habita, de facto, todos os nossos estados de consciência e executa realmente a-síntese suprema da nossa experiência? Parece que isso seria forçar o pensamento kantiano. Sendo o problema da crítica um problema de direito, Kant nada afirma sobre a existência de facto do Eu Penso. Parece, ao contrário, que ele viu perfeitamente que havia momentos de consciência sem "Eu", pois ele diz: "deve poder acompanhar". Trata-se, com efeito, de determinar as condições de possibilidade da experiência. Uma dessas condições é que eu possa sempre con- 
siderar a minha perceção ou o meu pensamento como meu: eis tudo. Mas há uma tendência perigosa da filosofia contemporânea - da qual encontraremos as marcas no neokantismo, no empiriocriticismo e num intelectualismo como o de Brochard - que consiste em realizar as condições de possibilidade determinadas pela crítica. É uma tendência que leva certos autores, por exemplo, a perguntarem-se que pode ser a "consciência transcendental". Se pomos a questão nestes termos, somos naturalmente coagidos a conceber esta consciência - que constitui a nossa consciência empírica - como um inconsciente. Mas Boutroux, nas suas lições sobre a filosofia de Kant, mostrava já a verdade destas interpretações. Kant não se preocupou nunca com o modo como se constitui de facto a consciência empírica, ele não a deduziu, ao modo de um processo neoplatónico, de uma consciência superior, de uma hiperconsciência constituinte. A consciência transcendental é para ele somente o conjunto das condições necessárias para a existência de uma consciência empírica. Por conseguinte, realizar o Eu transcendental, fazer dele o companheiro inseparável de cada uma das nossas "consciências", é julgar a respeito do facto e não a respeito do direito, é colocar-se num ponto de vista radicalmente diferente do de Kant. E se, todavia, alguém pretende apoiar-se nas considerações kantianas sobre a unidade necessária à experiência, comete o mesmo erro dos que fazem da consciência transcendental um inconsciente pré-empírico.

Se concedemos a Kant a questão de direito, a questão de facto não está igualmente decidida. É, portanto, conveniente formulá-la aqui nitidamente: 0 Eu Penso deve poder acompanhar todas as nossas representações, mas acompanha-as de facto? Suponhamos, além disso, que uma certa representação $A$ passa de um certo estado onde o Eu Penso não a acompanha para um estado onde o Eu Penso a acompanha - resultara para ela uma modificação de estrutura no antes permanecera ela inalterada no seu fundo? Esta segunda pergunta leva-nos a fazer uma terceira: o Eu Penso deve poder acompanhar todas as nossas representações; mas deve entender-se com isso que a unidade das nossas representações é, direta ou indiretamente, realizada pelo Eu Penso - ou deve entender-se antes que as representações de uma consciência devem estar unidas e articuladas de tal modo que um "Eu Penso" verificativo seja sempre, a seu propósito, possível? Esta terceira pergunta parece fazer-se sobre o terreno do direito e abandonar, nesse terreno, a ortodoxia kantiana. Mas trata-se, na realidade, de uma questão de facto, que se pode formular assim: o Eu que nós encontramos na nossa consciência é tomado possível pela unidade sinté-

1 Empregarei aqui o termo "consciência" para traduzir a palavra alemã "Bewusstsein", que significa ao mesmo tempo a consciência total, a mónada, e cada momento dessa consciência. A expressão "estado de consciência" parece-me inexata, por causa da passividade que ela introduz na consciência. 
tica das nossas representações ou é antes ele que unifica de facto as representações entre si?

Se nós abandonarmos todas as interpretações mais ou menos forçadas que os neokantianos fizeram do "Eu Penso" e se, no entanto, quisermos resolver o problema da existência de facto do Eu na consciência, encontramos no nosso caminho a fenomenologia de Husserl. A fenomenologia é um estudo científico e não crítico da consciência. O seu procedimento essencial é a intuição. A intuição, segundo Husserl, põe-nos na presença da coisa. Deve entender-se que a fenomenologia é, portanto, uma ciência de facto e que os problemas que ela põe são problemas de facto, ${ }^{2}$ como aliás se pode ainda perceber considerando que Husserl a denomina uma ciência descritiva. Os problemas das relações do Eu com a consciência são, portanto, problemas existenciais. Husserl reencontra e apreende a consciência transcendental de Kant através da epoché. Mas esta consciência já não é um conjunto de condições lógicas, é um facto absoluto. Não é já também uma hipóstase do direito, um inconsciente flutuando entre o real e o ideal. É uma consciência real, acessível a cada um de nós a partir do momento em que executa a "redução". Mantém-se que é mesmo ela que constitui a nossa consciência empírica, essa consciência "no mundo", essa consciência com um "eu" psíquico e psicofísico. Nós cremos de bom grado, pela nossa parte, na existência de uma consciência constituinte. Seguimos Husserl em cada uma das suas admissíveis descrições, em que ele mostra a consciência transcendental constituindo o mundo e aprisionando-se na consciência empírica; estamos persuadidos tal como ele que o nosso eu psíquico e psicofísico é um objeto transcendente que deve ficar ao alcance

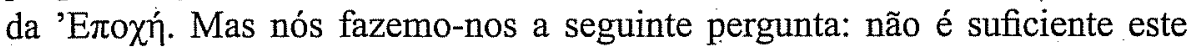
eu psíquico e psicofísico? Será preciso duplicá-lo por um Eu transcendental, estrutura da consciência absoluta? Veem-se as consequências da resposta. Se ela é negativa, resulta daí:

1. ${ }^{\circ}$ que o campo transcendental toma-se impessoal ou, se se prefere, "pré-pessoal", ele não tem Eu;

$2 .^{\circ}$, que o Eu não aparece senão ao nível da humanidade e não é senão uma face do eu, a face ativa;

3. ${ }^{\circ}$, que o Eu Penso pode acompanhar todas as nossas representações porque surge sobre um fundo de unidade que ele não contribui para criar e que é estạ unidade prévia que, ao contrário, o toma possível;

2 Husserl diria: uma ciência de essências. Mas, para o ponto de vista em que nos colocamos, isso vem dar ao mesmo. 
4. ${ }^{\circ}$, que seria lícito perguntar se a personalidade (mesmo a personalidade abstrata de um Eu) é um acompanhante necessário de uma consciência ou se não se pode conceber consciências absolutamente impessoais.

Ora Husserl respondeu à pergunta. Depois de ter considerado que o Eu $[M o i]^{3}$ era uma produção sintética e transcendente da consciência (nas Logische Untersuchungen), retornou, nas Ideen, à tese clássica de um Eu transcendentál que estaria como que por detrás do cada consciência, que seria uma estrutura necessária dessas consciências cujos raios (Ichstrahl) cairiam sobre cada fenómeno que se apresentasse no campo da atenção. Assim, a consciência transcendental toma-se rigorosamente pessoal. Esta conceção é necessária? É ela compatível com a definição que Husserl dá da consciência?

Crê-se ordinariamente que a existência de um Eu transcendental se justifica pela necessidade de unidade e de individualidade da consciência. É porque todas as minhas perceções e todos os meus pensamentos se referem a este foco permanente que a consciência está unificada; é porque posso dizer a minha consciência e porque Pedro e Paulo podem também falar da sua consciência que estas consciências se distinguem entre si. O Eu é produtor de interioridade. Ora é certo que a fenomenologia não tem necessidade de recorrer a este Eu unificador e individualizante. Com efeito, a consciência define-se pela intencionalidade. Pela intencionalidade, ela transcende-se a si mesma, ela unifica-se escapando-se. A unidade da miríade de consciências ativas pelas quais juntei, junto e juntarei dois com dois para fazer quatro é o objeto transcendente "dois mais dois são quatro". Sem a permanência desta verdade eterna, seria impossível conceber uma unidade real e haveria tantas operações irredutíveis quantas as consciências operatórias. É possível que os que creem ser "2 mais 2 são 4" o conteúdo da minha representação sejam obrigados a recorrer a um princípio transcendental e subjetivo de unificação, o qual seria então o Eu. Mas, justamente, Husserl não tem necessidade disso. $O$ objeto é transcendente às consciências que o apreendem e é nele que se encontra a sua unidade. Dirão que, todavia, é necessário um princípio de unidade na duração para que o fluxo continuado das consciências seja suscetivel de pôr objetos transcendentes fora dele. É necessário que as consciências sejam sínteses perpétuas das consciências passadas e da consciência presente. É exato. Mas é característico

${ }^{3}$ Sartre distingue entre o Je, como pólo dos atos, e o Moi, como pólo dos estados. Porque essa distinção não pode ser dada em português pelo recurso a duas palavras diferentes, uma vez que, tanto num como noutro caso, se impõe a tradução por Eu, adotamos o seguinte procedimento: sempre que, no texto original, aparece $J e$, traduzimos simplesmente por $E u$, sem dar qualquer outra indicação suplementar; sempre que é Moi que ocorre, inserimos entre parenteses retos, a seguir à tradução, a expressão original, como é aqui o caso. ( N. do T.) 
que Husserl, que estudou em $A$ Consciência Interna do Tempo esta unificação subjetiva das consciências, não tenha nunca recorrido a um poder sintético do Eu. É a consciência que se unifica a si mésma e, concretamente, por um jogo de intencionalidades "transversais", que são retenções concretas e reais das consciências passadas. Assim, a consciência remete perpetuamente para si mesma, quem diz "uma consciência" diz toda a consciência e esta propriedade singular pertence à própria consciência, sejam quais forem, para além disso, as suas relações com o Eu. Parece que Husserl, nas Meditações Cartesianas, conservou inteiramente esta conceção da consciência unificando-se no tempo. Por outro lado, a individualidade da consciência provém evidentemente da natureza da consciência. A consciência não pode ser limitada (como a substância de Espinosa) senão por ela mesma. Ela constitui, portanto, uma totalidade sintética e individual inteiramente isolada das outras totalidades do mesmo tipo e o Eu não pode ser, evidentemente, senão uma expressão (e não uma condição) desta incomunicabilidade e interioridade das consciências. Podemos portanto responder sem hesitar: a conceção.fenomenológica da consciência toma totalmente inútil o papel unificante e individualizante do Eu. É, ao contrário, a consciência que toma possível a unidade e a personalidade do meu Eu. O Eu transcendental não tem, portanto, razão de ser.

Mas, além disso, este Eu supérfluo é nocivo. Se ele existisse, arrancaria a consciência de si mesma, dividi-la-ia, insinuar-se-ia em cada consciência como uma lamela opaca. O Eu transcendental é a morte da consciência. Com efeito, a existência da consciência é um absoluto porque a consciência está consciente dela mesma. Isto quer dizer que o tipo de existência da consciência é o de ser consciência de si. E ela toma consciência de si enquanto ela é a consciência de um objeto transcendente. Tudo é, portanto, claro e lúcido na consciência: o objeto está face a ela com a sua opacidade característica, mas ela, ela é pura e simplesmente consciência de ser consciência desse objeto, é a lei da sua existência. É preciso acrescentar que esta consciência de consciência - fora os casos de consciência refletida, sobre os quais falaremos daqui a pouco - não é posicional, o que quer dizer que a consciência não é para si mesma o seu objeto. O seu objeto está, por natureza, fora dela e é por isso que, por um mesmo ato, ela o põe e o apreende. Ela mesma não se conhece senão com interioridade absoluta. Designaremos tal consciência como consciência do primeiro grau ou irrefletida. Nós perguntamos: há lugar para um $E u$ numa tal consciência? A resposta é clara: evidentemente que não. Com efeito, este Eu não é nem o objeto (pois que ele é interior por hipótese) nem também algo da consciência, pois que ele é qualquer coisa para a consciência; não uma qualidade translúcida da consciência, mas, de algum modo, um habitante. Com efeito, o Eu, com a sua personalidade, por mais formal e abstrato que o suponhamos, é como que um centro de opacidade. Ele é rela- 
tivamente ao eu concreto e psicofísico o que o ponto é relativamente às três dimensões: a um $\mathrm{Eu}$ [Moi] infinitamente contraído. Se, por conseguinte, se introduz esta opacidade na consciência, destruímos com isso a tão fecunda definição que há pouco dávamos, cristalizamo-la, obscurecêmo-la, ela já não é uma espontaneidade, ela traz nela mesma como que um gérmen de opacidade. Mas, além disso, somos coagidos a abandonar esse ponto de vista original e profundo que faz da consciência um absoluto não substancial. Uma consciência pura é um absoluto muito simplesmente porque é consciência dela mesma. Ela permanece, portanto, um "fenómeno" no sentido muito particular em que "ser" e "aparecer" são apenas um. Toda ela é ligeireza, toda ela é translucidez. É nisso que o Cogito de Husserl difere tanto do Cogito cartesiano. Mas se o Eu é uma estrutura necessária da consciência, esse Eu opaco é, de um mesmo lance, elevado ao nível de um absoluto. Eis-nos, portanto, na presença de uma mónada. E é precisamente essa, infelizmente, a orientação do novo pensamento de Husserl (ver as Meditações Cartesianas). A consciência tornou-se pesada, ela perdeu esse carácter que fazia dela o existente absoluto à força de inexistência. Ela é pesada e ponderável. Todos os resultados da fenomenologia ameaçam entrar em ruína se o Eu não é, do mesmo modo que o mundo, um existente relativo, quer dizer, um objeto para a consciência.

\section{B) O COGITO COMO CONSCIÊNCIA REFLEXIVA}

O "Eu penso" kantiano é uma condição de possibilidade. O Cogito de Descartes e de Husserl é a verificação de um facto: Falou-se da "necessidade de facto" do Cogito e essa expressão parece-me muito apropriada. Ora é inegável que o Cogito é pessoal. No "Eu penso" há um Eu que pensa. Atingimos aqui o Eu na sua pureza e é precisamente do Cogito que uma "Egologia" deve partir. O facto que pode servir de ponto de partida é, portanto, este: de cada vez que nos apreendemos o nosso pensamento, seja por uma intuição imediata seja por uma intuição apoiada na memória, nós apreendemos um $E u$, que é o Eu do pensamento apreendido; e que se dá, além disso, como transcendendo esse pensamento e todos as outros pensamentos possíveis. Se, por exemplo, quero lembrar-me de tal paisagem vista ontem no comboio, é-me possível fazer voltar a recordação dessa paisagem enquanto tal, posso também recordar que $e u$ via essa paisagem. É o que Husserl chama, em A Consciência Interna do Tempo, a possibilidade de refletir na recordação. Dito de outro modo, eu posso sempre operar uma qualquer rememoração sob o modo pessoal e o $E u$ aparece no mesmo instante. Tal é a garantia de facto da afirmação kantiana de direito. Assim se toma compreensível que não há sequer uma das minhas consciências que eu não apreenda como provida de um Eu. 
Mas é necessário recordarmos que todos os autores que descreveram o Cogito o apresentaram como uma operação reflexiva, quer dizer, como uma operação de segundo grau. Este Cogito é executado por uma consciência dirigida sobre a consciência, que toma a consciência como objeto. Entendamo-nos: a certeza do Cogito é absoluta pois, como o diz Husserl, há uma unidade indissolúvel da consciência refletinte e da consciência refletida (a tal ponto que a consciência refletinte não poderia existir sem a consciência refletida). Não é menos verdade que estamos na presença de uma síntese de duas consciências, das quais uma é consciência da outra. Assim, o princípio essencial da fenomenologia, "toda a consciência é consciência de qualquer coisa", está salvaguardado. Ora a minha consciência refletinte não se toma ela mesma como objeto quando eu executo o Cogito. O que ela afirma diz respeito à consciência refletida. Tanto quanta a minha consciência refletinte é consciência dela mesma, ela é consciência não posicional. Ela não se toma posicional senão ao visar a consciência refletida, a qual, ela mesmà, não era consciência posicional de si antes de ser refletida. Assim, a consciência que diz "Eu penso" não é precisamente aquela que pensa. Ou antes, não é o seu pensamento que ela põe através deste ato tético. Temos, portanto, razões para perguntar se o $E u$ que pensa é comum às duas consciências sobrepostas ou se ele não é antes o da consciência refletida. Toda consciência refletinte é, com efeito, nela mesma, irrefietida e é preciso um ato novo do terceiro grau para a pôr. Não há aqui, por outro lado, regressão ao infinito, já que uma consciência não tem, de modo nenhum, necessidade de uma consciência refletinte para ser consciência dela mesma. Simplesmente, ela não se põe a ela mesma como seu objeto.

Mas não seria precisamente o ato reflexivo que faria nascer o Eu [Moi] na consciência refletida? Assim se explicaria que todo e qualquer pensamento apreendido pela intuição possui um $\mathrm{Eu}$, sem cairmos nas dificuldades que o nosso capítulo precedente assinalava. Husserl é o primeiro a reconhecer que um pensamento irrefletido sofre uma mutação radical ao se tomar refletido. Mas dever-se-á limitar esta modificação a uma perda de "ingenuidade"? O essencial da mudança não seria a aparição do Eu? É preciso, evidentemente, recorrer à experiência concreta e esta pode parecèr impossível porque, por definição, uma experiência deste género é reflexiva, quer dizer, provida de um $\mathrm{Eu}$. Mas toda a consciência irrefletida, sendo consciência não-tética dela mesma, deixa uma lembrança não-tética que se pode consultar. Basta para isso procurar reconstituir o momento completo em que apareceu esta consciência irrefletida (o que é, por definição, sempre possível). Por exemplo, eu estava, mesmo agora, absorvido na minha leitura. Procurarei recordar-me das circunstâncias da minha leitura, a minha atitude, as linhas que lia. Vou assim.ressus- 
citar não só estes detalhes exteriores, mas uma certa espessura de consciência irrefletida, já que os objetos não puderam ser percecionados senão por esta consciência e lhe permanecem relativos. Quanto a esta consciência; não se deve pô-la como objeto da minha reflexão; ao contrário, é preciso que eu dirija a minha atenção para os objetos ressurgidos, mas sem a perder de vista, mantendo com ela uma espécie de cumplicidade e inventariando o seu conteúdo de modo não-posicional. O resultado não oferece dúvidas: enquanto lia, havia consciência do livro, dos heróis do romance, mas o Eu não habitava esta consciência, ela era somente consciência de objeto e consciência não-posicional dela mesma. Uma vez apreendidos ateticamente estes resultados, posso agora fazê-los objeto de uma tese e declarar: não havia $E u$ na consciência irrefletida. Não se deve considerar esta operação como artificial e inventada de propósito para este caso: é evidentemente graças a ela que Titchener podia dizer, no seu Texbook of Psychology, que muitas vezes o Eu [Moi] estava ausente da sua consciência. Ele não ia, de resto, mais longe e não tentava classificar os estados de consciência sem Eu [Moi].

Alguém estava, sem dúvida, tentado a objetar-me que esta operação, esta apreensão não-reflexiva de uma consciência por uma outra consciência, não pode, evidentemente, operar-se a não ser pela memória e que ela não beneficia, portanto, da certeza absoluta inerente ao ato reflexivo. Encontrar-nos-íamos, portanto, na presença, por um lado, de um ato certo que me permite afirmar a presença do Eu na consciência refletida e, por outro lado, de uma recordação duvidosa que tenderia a fazer crer que o Eu está ausente da consciência irrefletida. Parece que não temos o direito de opor uma coisa a outra. Mas peço que se considere que a recordação da consciência irrefletida não se opõe aos dados da consciência reflexiva. Ninguém sonha negar que o Eu apareça numa consciência refletida. Trata-se simplesmente de opor a recordação reflexiva da minha leitura ("eu lia"), que é, ela também, de natureza duvidosa, a uma recordação não-refletida. $O$ direito da reflexão presente não se estende, com efeito, para lá da consciência presentemente apreendida. E a recordação reflexiva, à qual estamos obrigados a recorrer para restituir as consciências passadas, além do carácter duvidoso que ela deve à sua natureza de recordação, permanece suspeita, já que, segundo o que o próprio Husserl confessa, a reflexão modifica a consciência espontânea. Visto que, portanto, todas as recordações não-reflexivas da consciência irrefletida me mostram uma consciência sem $e u$, visto que, por outro lado, considerações teóricas, baseadas na intuição de essência da consciência, nos levaram a reconhecer que o Eu não podia fazer parte da estrutura interna das "Erlebnisse", temos, portanto, que concluir: não há $E u$ no plano irrefletido. Quando corro atrás de um carro elétrico, quando vejo as horas, quando me absorvo na contemplação de um retrato, não há Eu. 
Há consciência do-carro-elétrico-que-deve-ser-apanhado, etc., è consciência não-posicional da consciência. De facto, estou então mergulhado no mundo dos objetos, são eles que constituem a unidade das minhas consciências, que se apresentam com valores, qualidades atrativas ou repulsivas, mas $e u$, eu desapareci, eu anulei-me. Não há lugar para mim a este nível e isto não provém de um acaso, de uma falta de atenção momentânea, mas da própria estrutura da consciência.

É o que uma descrição do Cogito nos tomará mais palpável ainda. Poder-se-á dizer, com efeito, que o ato reflexivo apreenda no mesmo grau e da mesma maneira o Eu e a consciência pensante? Husserl insiste no facto de que a certeza do ato reflexivo provém de que nós aí apreendemos a consciência sem ser por facetas, por perfis, mas por inteiro (sem "Abschattungen"). Isso é evidente. Pelo contrário, o objeto espácio-temporal dá-se sempre através de uma infinidade de aspetos e não é, no fundo, senão a unidade ideal dessa infinidade. Quanto às significações, às verdades eternas, elas afirmam a sua transcendência por se darem, desde que aparecem, como independentes do tempo, enquanto que a consciência que as apreende está, ao contrário, rigorosamente individualizada na duração. Ora nós perguntamos: quando uma consciência reflexiva apreende o Eu penso, entrega-se ela à apreensão de uma consciência plena e concreta aglutinada num momento real da duração concreta? A resposta é clara: o Eu não se dá como um momento concreto, como uma estrutura perecível da minha consciência atual; ele afirma, ao contrário, a sua permanência para lá desta consciência e de todas as consciências e - se bem que, certamente, ele não se pareça com uma verdade matemática - o seu tipo de existência aproxima-se muito mais do das verdades eternas do que do da consciência. É mesmo evidente que foi por ter acreditado que Eu e penso estão no mesmo plano que Descartes passou do Cogito à idéia de substância pensante. Vimos há pouco que Husserl, se bem que mais subtilmente, cai no fundo na mesma falta. Bem sei que ele reconhece ao Eu uma transcendência especial, que não é a do objeto, e que poderíamos chamar uma transcendência "pelo lado de cima". Mas com que direito? E como explicar este tratamento privilegiado do Eu a não ser por preocupações metafísicas ou críticas que não têm nada que ver com a fenomenologia? Sejamos mais radicais e afurmemos sem temor que toda a transcendência deve ficar ao alcance da epoché; isso evitar-nos-á, talvez, escrever capítulos tão embaraçados como o $§ 61$ das Ideen. Dado que o Eu se afirma ele mesmo como transcendente no "Eu penso", é porque ele não é da mesma naturezạ que a consciência transcendental.

Observemos, ademais, que ele não aparece à reflexão como a consciência refletida: ele dá-se através da consciência refletida. Certamente, ele é apreendido pela intuição e é objeto de uma evidência. Mas sabe-se o serviço 
que Husserl prestou à filosofia ao distinguir diversas espécies de evidência. Pois bem, é por demais certo que o Eu do Eu penso não é objeto nem de uma evidência apodítica nem de uma evidência adequada. Ela não é apodítica visto que, ao dizer $E u$, afirmamos bem mais do que sabemos. Ela não a adequada; pois o Eu apresenta-se como uma realidade opaca, de que seria preciso desdobrar o conteúdo. Certamente que ele se manifesta como a fonte da consciência, mas isso deveria fazer-nos refletir: com efeito, por esse facto, ele aparece velado, pouco distinto através da consciência, como uma pedra no fundo da água, - por esse facto, ele é, em seguida, enganador, pois sabemos que nada salvo a consciência pode ser a fonte da consciência. Além disso, se o Eu faz parte da consciência, haveria, portanto, dois Eus: o Eu da consciência reflexiva e o Eu da consciência refletida. Fink, o discípulo de Husserl, conhece mesmo um terceiro, o Eu da consciência transcendental, liberado pela epoché. Daí o problema dos três Eus, de que ele menciona com alguma complacência as dificuldades. Para nós, esse problema é, muito simplesmente insolúvel, pois não é admissível que se estabeleça uma comunicação entre o Eu reflexivo e o Eu refletido, se eles são elementos reais da consciência, nem sobretudo que eles finalmente se identifiquem num Eu único.

Como conclusão desta análise, parece-me que se pode fazer as seguintes verificações:

1. O Eu é um existente. Ele tem um tipo de existência concreta, sem dúvida diferente da das verdades matemáticas, das significações ou dos seres espácio-temporais, mas também real. Dá-se, ele próprio, como transcendente.

2. Ele dá-se a uma intuição de um género especial, que o apreende por detrás da consciência refletida, de um modo sempre inadequado.

3. Ele não aparece nunca senão por ocasião de um ato reflexivo. Neste caso, a estrutura complexa da consciência é a seguinte: há um ato irrefletido de reflexão sem Eu que se dirige para uma consciência refletida. Esta toma-se o objeto da consciência refletinte, sem deixar, todavia, de afirmar o seu objeto próprio (uma cadeira, uma verdade matemática, etc.). Ao mesmo tempo, um objeto novo aparece, o qual é a ocasião de uma afirmação da consciência reflexiva e não está, por conseguinte, nem no mesmo plano da consciência irrefletida (porque esta é um absoluto que não precisa da consciência reflexiva para existir) nem no mesmo plano do objeto da consciência irrefletida (cadeira, etc.). Este objeto transcendente do ato reflexivo é o Eu.

4. O Eu transcendental deve ficar ao alcance da redução fenomenológica. O Cogito afirma de mais. O conteúdo certo do pseudo-Cogito não é "eu tenho consciência desta cadeira", mas "há consciência desta cadeira". Este conteúdo é suficiente para constituir um campo infinito e absoluto para as investigações da fenomenologia. 


\section{C) TEORIA DA PRESENÇA MATERIAL DO EU [MOI]}

Para Kant e para Husserl, o Eu é uma estrutura formal da consciência. Tentámos mostrar que um Eu não é nunca puramente formal, que ele é sempre, mesmo abstratamente concebido, uma contração infinita do Eu [Moi] material. Mas precisamos, antes de irmos mais longe, de nos desembaraçar de uma teoria puramente psicológica que afirma, por razões de ordem psicológica, a presença material do $\mathrm{Eu}[\mathrm{Moi}]$ em todas as nossas consciências. É a teoria dos moralistas do "amor-próprio". Segundo eles, o amor de si mesmo - e, por conseguinte, o $\mathrm{Eu}[\mathrm{Moi}]$ - estaria dissimulado em todos os sentimentos sob uma miríade de formas diversas. De um modo muito geral, o Eu [Moi], em função desse amor que ele se tem, desejaria para si mesmo todos os objetos que deseja. A estrutura essencial de cada um dos meus atos seria uma chamada a mim. O "retorno a mim" seria constitutivo de toda a consciência.

Objetar a esta tese que esse retorno a mim não está de modo nenhum presente para a consciência - por exemplo, quando tenho sede, que vejo um copo de água e que ele me aparece como desejável - não é ainda embaraçá-la: ela concedê-lo-ia de boa vontade. La Rochefoucauld foi um dos primeiros a fazer uso, sem o nomear, do inconsciente: para ele, o amor-próprio dissimula-se sob as mais diversas formas. É preciso seguir-lhe a pista antes de o apreender. De um modo mais geral, admitiu-se de seguida que o Eu [Moi], se não está presente para a consciência, está escondido por detrás dela e que ele é o.pólo de atracão de todas as nossas representações e de todos os nossos desejos. $\mathrm{O}$ Eu [Moi] procura, portanto, alcançar o objeto para satisfazer o seu desejo. Dito de outro modo, é o desejo (ou, se se prefere, o Eu [Moi] desejante) que é dado como fim, e é o objeto desejado que é meio.

Ora o interesse desta tese parece-nos ser o de pôr em relevo um erro muito frequente dos psicólogos: consiste ele em confundir a estrutura essencial dos atos reffexivos com a dos atos irrefletidos. Ignora-se que há sempre duas formas de existência possível para uma consciência; e, de cada vez que as consciências observadas se dão como irrefletidas, sobrepõe-se-lhes uma estrutura reflexiva que se pretende atabalhoadamente que permanece inconsciente.

Tenho piedade de Pedro e socorro-o. Para a minha consciência, só existe uma coisa nesse momento: Pedro-que-deve-ser-socorrido. Esta qualidade de "deve-ser-socorrido" encontra-se em Pedro. Ela age sobre mim como uma força. Aristóteles disse-o: é o desejável que move o desejante. A este nível, o desejo é dado à consciência como centrífugo (ele transcende-se a si mesmo, ele é consciência tética do "dever-ser" e consciência não-tética dele mesmo) e impessoal (não há Eu [Moi]: eu estou face à dor de Pedro como face à cor deste tinteiro. Há um mundo objetivo de coisas e de ações, feitas ou a fazer, e as ações apõem-se como qualidades sobre as coisas que as reclamam). 
Ora este primeiro momento do desejo - supondo que ele não tenha escapado completamente aos teóricos do amor-próprio - não é por eles considerado como um momento completo e autónomo. Imaginaram por detrás dele um outro estado que permanece na penumbra: por exemplo, eu socorro Pedro para fazer cessar o estado desagradável em que me pôs a visão dos seus sofrimentos. Mas este estado desagradável não pode ser conhecido como tal e não se pode tentar suprimi-lo senão no seguimento de um ato de reflexão. Com efeito, um desagrado sob o plano irrefletido transcende-se da mesma maneira que a consciência irrefletida de piedade. É a apreensão intuitiva de uma qualidade desagradável de um objeto. E, na justa medida em que ele pode ser acompanhado por um desejo, ele deseja não suprimir-se a si mesmo, mas suprimir o objeto desagradável. Não serve, portanto, para nada pôr, por detrás da consciência irrefletida de piedade, um estado desagradável de que se faria a causa profunda do ato piedoso: se esta consciência de desagrado não retoma a si mesma para se pôr por si como estado desagradável, permaneceremos indefinidamente no impessoal e no irrefletido. Assim, portanto, sem se darem conta disso, os teóricos do amor-próprio supõem que o refletido é primeiro, original e dissimulado no inconsciente. Quase que não é preciso fazer notar à absurdidade de uma tal hipótese. Mesmo se o inconsciente existe, a quem se poderia fazer crer que ele encerra espontaneidades de forma refletida? A definição do refletido não é o ser ele posto por uma consciência? Mas, além disso, como admitir que o refletido é primeiro em relação ao irrefletido? Sem dúvida, pode conceber-se, em certos casos, que uma consciência apareça imediatamente como refletida. Mas mesmo então o irrefletido tem prioridade ontológica sobre o refletido, porque ele não tem de nenhum modo necessidade de ser refletido para existir e porque a reflexão supõe a intervenção de uma consciência de segundo grau.

Chegamos, portanto, à seguinte conclusão: a consciência irrefletida deve ser considerada autónoma. É uma totalidade que não tem necessidade nenhuma de ser completada e devemos reconhecer sem mais que a qualidade própria do desejo irrefletido é a de se transcender, apreendendo no objeto a qualidade de desejável. Tudo se passa como se nós vivêssemos num mundo em que os objetos, além das suas qualidades de calor, odor, forma, etc., tivessem as de repulsivo, atrativo, encantador, útil, etc., etc., é como se essas qualidades fossem forças que exercessem sobre nós certas ações. No caso da reflexão, e apenas nesse caso, a afetividade é posta por ela mesma como desejo, temor, etc., somente no caso da reflexão posso pensar "Eu odeio Pedro", "Eu tenho. piedade de Paulo", etc. É, portanto, contrariamente ao que se defendeu, sobre este plano que se situa a vida egoísta e sobre o plano irrefletido que se situa a vida impessoal (o que não quer dizer, naturalmente, que toda a vida reflexiva é forçosamente egoísta, nem que toda a vida irrefletida é forçosamente altruísta). 
A reflexão "envenena" o desejo. No plano irrefletido, eu socorro Pedro porque Pedro é "deve-ser-socorrido". Mas se, de súbito, o meu estado se transforma em estado refletido, eis-me então em vias de me observar a agir, no sentido em que se diz de alguém que ele se ouve a si mesmo ao falar. Já não é.Pedro que me atrai, é a minha consciência socorrista que me aparece como devendo ser perpetuada. Mesmo se eu apenas penso que devo prosseguir a minha ação porque "isso é bom", o bem qualifica a minha conduta, a minha piedade, etc. A psicologia de La Rochefoucauld encontra-se no seu lugar. $\mathrm{E}$, contudo, ela não é verdadeira: não é culpa minha se a minha vida reflexiva envenena "por essência" a minha vida espontânea e, além do mais, a vida reflexiva supõe em geral a vida espontânea. Antes de terem sido "envenenados", os meus desejos foram puros; é o ponto de vista que tomei sobre eles que os envenenou. A psicologia de La Rochefoucauld não é verdadeira senão para os sentimentos particulares que tem a sua origem na vida reflexiva, quer dizer, que se dão desde logo como meus sentimentos em vez de se transcenderem primeiramente para um objeto.

Assim, o estudo puramente psicológico da consciência "intramundana" leva-nos às mesmas conclusões que o nosso estudo fenomenológico: o eu não deve ser procurado nem nos estados irrefletidos de consciência nem por detrás deles. O Eu [Moi] aparece apenas com o ato reflexivo e como correlato noemático de uma intenção reflexiva. Começamos a entrever que Eu e Mim [le Je et le Moi] não são senão um. Vamos tentar mostrar que este Ego, de que Eu e Mim não são senão duas faces, constitui a unidade ideal (noemática) e indireta da série infinita das nossas consciências refletidas.

"Eu" é o Ego como unidade das ações. "Mim" é o Ego como unidade dos estados e das qualidades. A distinção que se estabelece entre estes dois aspetos de uma mesma realidade parece-nos ser simplesmente funcional, para não dizer gramatical.

\section{II}

\section{CONSTITUIÇÃO DO EGO}

O Ego não é, diretamente, unidade das consciências refletidas. Existe uma unidade imanente destas consciências: é o fluxo da consciência que sè constitui ele mesmo como unidade dele mesmo ${ }^{4}$ - e uma unidade transcendente: os 
estados e as ações. O Ego é unidade dos estados e das acções - facultativamente, das qualidades. Ele é unidade de unidades transcendentes e é ele mesmo transcendente. É um pólo transcendente de unidade sintética, tal como o pólo-objeto da atitude irrefletida. Só que este pólo aparece apenas no mundo da reflexão. Vamos examinar sucessivamente a constituição dos estados, das ações, das qualidades e a aparição do.Eu [Moi] como pólo destas tranșcendências.

\section{A) OS ESTADOS COMO UNIDADES TRANSCENDENTES DAS CONSCIÊNCIAS}

$\mathrm{O}$ estado aparece à consciência reflexiva. Ele dá-se-lhe e constitui o objeto de uma intuição concreta. Se odeio Pedro, o meu ódio a Pedro é um estado que posso apreender pela reflexão. Este estado está presente diante do olhar da consciência reflexiva, ele é real. Deve concluirir-se daí que ele é imanente e certo? Certamente que não. Nós não devemos fazer da reflexão um poder misterioso a infalível, nem acreditar que tudo o que a reflexão atinge é indubitável porque é atingido pela reflexão. A reflexão tem limites de direito e de facto. É uma consciência que põe uma consciência. Tudo o que ela afirma sobre esta consciência é certo e adequado. Mas se outros objetos the aparecem através desta consciência, esses objetos não têm nenhuma razão para participar nas características da consciência. Consideremos uma experiência reflexiva de ódio. Eu vejo Pedro, sinto uma profunda perturbação de repulsão e de cólera ao vê-lo (estou já no plano reflexivo); a perturbação é consciência. Não posso enganar-me quando digo: experimento, neste momento, uma violenta repulsão por Pedro. Mas o ódio é esta experiência de repulsão? Evidentemente que não: Ele não se dá, para além disso, como tal. Com efeito, odeio Pedro há muito e penso que o odiarei.sempre. Uma consciência instantânea de repulsão não poderia ser, portanto, o meu ódio. Se eu a limitasse ao que ela é, a uma instantaneidade, não poderia mesmo falar mais de ódio. Eu diria: "tenho repulsão por Pedro neste momento" e, dessa maneira, eu não comprometeria o futuro. Mas, precisamente por essa recusa de comprometer o futuro, eu cessaria de odiar.

Ora o meu ódio aparece-me ao mesmo tempo que a minha experiência de repulsão. Mas ele aparece através dessa experiência. Ele dá-se, precisamente, como não estando limitado a essa experiênciạ. Ele dá-se em e por cada movimento de descontentamento, de repulsão e de cólera, mas, ao mesmo tempo, ele não é nenhum deles, ele escapa a cada um deles afirmando a sua permanência. Ele afirma que aparecia já quando, ontem, pensei em Pedro com tanta fúria e que aparecerá amanhã. Ademais, ele opera por ele mesmo uma distinção entre ser e aparecer, visto que ele se dá como continuando a ser mesmo 
quando estou absorvido por outras ocupações e nenhuma consciência o revela. Eis o suficiente, parece, para poder afirmar que o ódio não é da consciência. Ele extravasa a instantaneidade da consciência e não se submete à lei absoluta da consciência, para a qual não há distinção possivel entre a aparência e o ser. O ódio é, portanto, um objeto transcendente. Cada "Erlebnis" revela-o por inteiro, mas ao mesmo tempo isso não é mais que um perfil, que uma projeção (uma "Abschattung"). O ódio é um título de crédito para uma infinidade de consciências coléricas ou repugnadas, no passado e no futuro. Ele é a unidade transcendente desta infinidade de consciências. Dizer "eu odeio", ou "eu amo" por ocasião de uma consciência singular de atração ou de repulsão é, também, operar uma verdadeira passagem ao infinito, bastante análoga à que operamos quando percecionamos um tinteiro ou o azul do mata-borrão.

Não é preciso mais para que os direitos da reflexão sejam singularmente limitados: é certo que Pedro me repugna, mas é e ficará para sempre duvidoso que eu o odeie. Com efeito, esta afirmação extravasa infinitamente o poder da reflexão. Não se deve, naturalmente, concluir que o ódio seja umą simples hipótese, um conceito vazio: é deveras um objeto real, que eu apreendo através da Erlebnis, mas este objeto está fora da consciência e a própria natureza da sua existência implica a sua "dubitabilidade". Deste modo, a reflexão tem um domínio certo e um domínio duvidoso, uma esfera de evidências adequadas e uma esfera de evidências inadequadas. A reflexão pura (que não é, no entanto, forçosamente a reflexão fenomenológica) atém-se ao dado sem manifestar pretensões quanto ao futuro. É o que se pode ver quando alguém, depois de ter dito em cólera: "eu detesto-te", cai em si e diz: "não é verdade, não te detesto, disse isso debaixo da cólera". Vemos aqui duas reflexões: uma, impura e cúmplice, que opera de imediato uma passagem ao infinito e que constitui bruscamente o ódio, através da Erlebnis, como seu objeto transcendente; a outra, pura, simplesmente descritiva, que serena a consciência irrefletida restituindo-lhe a sua instantaneidade. Estas duas reflexões apreenderam os mesmos dados certos, mas uma afirmou mais do que sabia e dirigiu-se, através da consciência refletida, para um objeto situado fora da consciência.

A partir do momento em que se deixa o domínio da reflexão pura ou impura e que se medita sobre os seus resultados, é-se tentado a confundir o sentido transcendente das Erlebnisse com o seu matiz imanente. Esta confusão conduz o psicólogo a dois tipos de erros: ou do facto de que me engano muitas vezes nos meus sentimentos, de, que, por exemplo me acontece crer que amo quando de facto odeio, concluo que a introspeção é enganadora; nesse caso, separo definitivamente o meu estado das suas aparições; considero que é preciso uma interpretação simbólica de todas as aparições (tomadas como símbolos) para determinar o sentimento e suponho uma relação de causalidade entre o sentimento e as suas aparições: eis o inconsciente que reaparece, - ou 
do facto de que sei, pelo contrário, que a minha introspeção é retá, que não posso duvidar da minha consciência de repulsão enquanto a tenho, creio-me autorizado a transportar esta evidência para o sentimento, concluo que o meu ódio pode encerrar-se na imanência e na adequação de uma consciência instantânea.

O ódio é um estado. E por esse termo tentei exprimir o carácter de passividade que lhe é constitutivo. Sem dúvida que se dirá que o ódio é uma força, um impulso irresistível, etc. Mas a corrente elétrica ou a queda de água são também forças temíveis: tira isso alguma coisa à passividade e inércia da sua natureza? Recebem menos, por isso, a sua energia de fora? A passividade de uma coisa espácio-temporal constitui-se a partir da sua relatividade existencial. Uma existência relativa só pode ser passiva, visto que a mínima atividade libertá-la-ia do relativo e constituí-la-ia num absoluto. Do mesmo modo, o ódio, existência relativa à consciência, é inerte. E, naturalmente, ao falar da inércia do ódio, só queremos dizer que ele aparece como tal à consciência. Não se diz, com efeito: "o meu ódio foi despertado...", "o seu ódio era contrariado pelo violento desejo de...", etc.? As lutas do ódio contra a moral, a censura, etc., não são figuradas como conflitos de forças fisicas, ao ponto de Balzac e a maior parte dos romancistas (por vezes, o próprio Proust) aplicarem aos estados o princípio da independência das forças? Toda a psicologia dos estados (e a psicologia não-fenomenológica em geral) é uma psicologia da inércia.

O estado é dado, de algum modo, como o intermediário entre o corpo (a "coisa" imediata) e a "Erlebnis". Só que ele não é dado como agindo do mesmo modo do lado do corpo e do lado da consciência. Do lado do corpo, a sua ação é francamente causal. Ele é causa da minha mímica, causa dos meus gestos: "por que razão foste tão desagradável para o Pedro?", "porque eu detesto-o". Mas não poderá ser do mesmo modo (salvo nas teorias construídas a priori e com conceitos vazios, como o freudismo) do lado da consciência. Em caso nenhum, com efeito, pode a reflexão ser enganada a respeito da espontaneidade da consciência refletida: é o domínio da certeza reflexiva. Deste modo, a relação entre o ódio e a consciência instantânea de desagrado é construída de modo a gerir ao mesmo tempo as exigências do ódio (ser primeiro, ser origem) e os dados certos da reflexão (espontaneidade): a consciência de desagrado aparece à reflexão como uma emanação espontânea do ódio. Vemos aqui, pela primeira vez, esta noção de emanação, que é tão importante de cada vez que se trata de ligar os estados psíquicos inertes às espontaneidades da consciência. A repulsão dá-se, de algum modo, como produzindo-se ela mesma por ocasião do ódio e à custa do ódio. O ódio aparece através dela como aquilo de onde ela emana. Reconhecemos de bom grado que a relação do ódio à "Erlebnis" particular de repulsão não é lógica. É um laço mágico, 
certamente. Mas nós quisemos apenas descrever e, de resto, veremos brevemente que é em termos exclusivamente mágicos que se deve falar das relações do eu com a consciência.

\section{B) CONSTITUIÇAO DAS $A C ̧ \tilde{O} E S$}

Não tentaremos estabelecer uma distinção entre a consciência ativa e a consciência simplesmente espontânea. Parece-nos, além disso, que se trata de um dos mais difíceis problemas da fenomenologia. Queríamos simplesmente observar que a ação concertada é, antes de tudo (e de qualquer natureza que seja a consciência ativa), um transcendente. Isso é evidente. Para ações como "tocar piano", "conduzir um automóvel", "escrever", porque essas ações são "tomadas" no mundo das coisas. Mas as ações puramente psíquicas, como duvidar, raciocinar, meditar, pôr uma hipótese, devem, elas também, ser concebidas como transcendências. O que engana aqui é que a ação não é simplesmente a unidade noemática de uma corrente de consciência: é também uma realização concreta. Mas não se deve esquecer que a ação pede tempo para se consumar. Ela tem articulações, momentos. A esses momentos correspondem consciências concretas ativas e a reflexão que se dirige sobre as consciências apreende a ação total, numa intuição que a dá como unidade transcendente das consciências ativas. Neste sentido, pode dizer-se que a dúvida espontânea que me invade quando entrevejo um objeto na penumbra é uma consciência, mas a dúvida metódica de Descartes é uma ação, quer dizer, um objeto transcendente da consciência reflexiva. Vê-se aqui o perigo: quando Descartes diz "duvido, logo sou", trata-se da dúvida espontânea que a consciência reflexiva apreende na sua instantaneidade - ou trata-se antes justamente do empreendimento de duvidar? Esta ambiguidade, vimo-lo, pode ser a fonte de graves erros.

\section{C) AS QUALIDADES COMO UNIDADES FACULTATIVAS DOS ESTADOS}

O Ego é diretamente, vamos vê-lo, a unidade transcendente dos estados e das ações. No entanto, pode existir um intermediário entre uns e outros: é a qualidade. Ao experimentarmos várias vezes ódio a diferentes pessoas, rancores tenazes ou longas cóleras, nós unificamos essas diyersas manifestações intentando numa disposição psíquica para as produzir. Esta disposição psíquica (eu sou muito rancoroso, sou capaz de odiar violentamente, sou colérico) é, naturalmente, mais e outra coisa que um simples termo médio. É um objeto transcendente. Ela representa o substrato dos estados, tal como os estados representam o substrato das "Erlebnisse". Mas a sua relação com os 
sentimentos não é uma relação de emanação. A emanação não religa senão as consciências às passividades psíquicas. A relação da qualidade ao estado (ou a ação) é uma relação de atualização. A qualidade é dada como uma potencialidade, uma virtualidade que, sob a influência de fatores diversos, pode passar a atualidade. A sua atualidade é precisamente o estado (ou a ação). Vê-se a diferença essencial entre a qualidade e o estado. $O$ estado é unidade noemática de espontaneidades, a qualidade é unidade de passividades objetivas. Na ausência de toda e qualquer consciência de ódio, o ódio dá-se como existindo em ato. Ao contrário, na ausência de todo sentimento de rancor, a qualidade correspondente permanece uma potencialidade. A potencialidade não é a simples possibilidade: ela apresenta-se como qualquer coisa que existe realmente, mas cujo modo de existência é o de estar em latência. Deste tipo são, naturalmente, os defeitos, as virtudes, os gostos, os talentos, as tendências, os instintos, etc. Estas unificações são sempre possíveis. A influência de ideias pré-concebidas e de fatores sociais é aqui preponderante. Pelo contrário, elas não são nunca indispensáveis, porque os estados e as ações podem encontrar diretamente no Ego a unidade que reclamam.

\section{D) CONSTITUIÇÃO DO EGo COMO PÓLO DAS AÇÕES, DOS ESTADOS E DAS QUALIDADES.}

Acabámos de aprender a distinguir o "psíquico" da consciência. O psíquico é o objeto transcendente da consciência reflexiva, ${ }^{5}$ é também o objeto da ciência denominada psicologia. $\mathrm{O}$ Ego aparece à reflexão como um objeto transcendente que realiza a síntese permanente do psíquico. O Ego está do lado do psíquico. Sublinhámos que o Ego que aqui consideramos é psíquico e não psicofísico. Não é por abstração que separamos estes dois aspetos do Ego. $\mathrm{O}$ Eu [Moi] psicofísico é um enriquecimento sintético do Ego psíquico, o qual pode muito bem (e sem redução de espécie alguma) existir em estado livre. É evidente que, por exemplo, quando se diz: "eu sou um indeciso", não se.visa diretamente o Eu [Moi] psicofísico.

Seria tentador constituir o Ego em "pólo-sujeito", como esse "pólo-objeto" que Husserl coloca no centro do núcleo noemático. Esse pólo-objeto é um X que suporta as determinações.

"Os predicados são predicados de "qualquer coisa", este "qualquer coisa" pertence também ao núcleo em questão e é patente que não pode

${ }^{5}$ Mas ele pode ser também visado e atingido através da perceção dos comportamentos. Nós tencionamos explicar-nos noutro lugar acerca da identidade de fundo de todos os métodos psicológicos. 
separar-se dele; ele é o ponto de unidade central de que falámos mais acima. Ele é o ponto de fixação dos predicados, o seu suporte; mas ele não é de modo algum unidade dos predicados, no sentido de um qualquer complexo, de uma qualquer ligação de predicados. Ele deve ser necessariamente distinguido deles, se bem que não se possa pô-lo ao lado deles nem separá-lo deles. Do mesmo modo, eles são seus predicados: "impensáveis sem ele e, no entanto, a distinguir deles". 6

Com isto pretende Husserl frisar que considera as coisas como sínteses pelo menos idealmente analisáveis. Sem dúvida, esta árvore, esta mesa são complexos sintéticos e cada qualidade está ligada a cada uma das outras. Mas ela está-lhes ligada enquanto pertence ao mesmo objeto $X$. O que,é logicamente primeiro são as relações unilaterais segundo as quais cada qualidade pertence (direta ou indiretamente) a este $\mathrm{X}$, como um predicado a um sujeito. Resulta daí que uma análise é sempre possível. Esta conceção é muito discutível. Mas não é este o lugar para a examinar. O que nos interessa é que uma totalidade sintéticá indissolúvel e que se suportasse a ela mesma não teria nenhuma precisão de um X suporte, com a condição, naturalmente, que ela seja real e concretamente inanalisável. É inútil, por exemplo, se se considera uma melodia, supor um $\mathrm{X}$ que serviria de suporte às diferentes notas. $\mathrm{A}$ unidade vem aqui da indissolubilidade absoluta dos elementos, que não podem ser concebidos como separados, salvo por abstração. O sujeito do predicado seria aqui a totalidade concreta e o predicado seria uma qualidade abstratamente separada da totalidade, que só toma todo o seu sentido se a ligarmos à totalidade: ${ }^{7}$

Por estas mesmas razões, recusaremos ver no Ego uma espécie de pólo $\mathrm{X}$ que seria o suporte dos fenómenos psíquicos. Um tal X seria, por definição, indiferente às qualidades psíquicas de que seria o suporte. Mas o Ego, como veremos, não é nunca indiferente aos seus estados, ele está "comprometido" com eles. Ora, precisamente, um suporte não pode estar assim comprometido com o que suporta senão no caso de ele ser uma totalidade concreta que suporta e contém as suas próprias qualidades. O Ego nada é fora da totalidade concreta dos estados e das ações que ele suporta. Sem dúvida que èle é transcendente a todos os estados que unifica, mas não como um $\mathrm{X}$ abstrato cuja missão é apenas unificar: é antes a totalidade infinita dos estados e das ações que se não deixa jamais reduzir a uma ação ou a um estado. Se procurássemos um análogo para a consciência irrefletida do que o Ego é para a consciência

\footnotetext{
${ }^{6}$ ldeen, $§ 131$, p. 270.

${ }^{7}$ Husserl conhece, alias, muito bem este tipo de totalidade sintética, à qual ele dedicou um escudo notável: $L U$ II, Unterstıchung III.
} 
de segundo grau, pensamos que se deveria antes considerar o Mundo, concebido como a totalidade sintética infinita de todas as coisas. Acontece também, com efeito, que apreendemos o Mundo, para lá da nossa cercania imediata, como uma vasta existência concreta. Neste caso, as coisas que nos cercam aparecem somente como a ponta extrema desse Mundo que as ultrapassa e as engloba. O Ego é para os objetos psíquicos o que o Mundo é para as coisas. Só que a aparição do Mundo como pano de fundo das coisas é bastante rara; são precisas circunstâncias especiais (muito bem descritas por Heidegger em Sein und Zeit) para que ele se "desvele". O Ego, ao contrário, aparece sempre no horizonte dos estados. Cada estado, cada ação dá-se como não podendo ser separada, sem abstração, do Ego. E se o juízo separa o Eu do seu estado (como na frase: $E u$ estou apaixonado), não é talvez senão para logo os ligar; o movimento de separação conduziria a uma significação vazia e falsa se não se desse ele próprio como incompleto e se não se completasse com um movimento de síntese.

Esta totalidade transcendente participa no carácter duvidoso de toda a transcendência; quer dizer que tudo o que nos dão as nossas intuições do Ego pode sempre ser contrạdito por intuições ulteriores e dá-se como tal. Por exemplo, posso ver com evidência que sou colérico, invejoso, etc., e no entanto posso enganar-me. Dito de outro modo, posso enganar-me ao pensar que tenho um tal Eu [Moi]. O erro não se comete, aliás, ao nível do juízo, mas antes já ao nível da evidência pré-judicativa. Este carácter duvidoso do meu Ego - ou mesmo o erro intuitivo que cometo - não significa que tenho um $\mathrm{Eu}$ [Moi] verdadeiro que ignoro, mas somente que o Ego visado traz em si mesmo o carácter da dubitabilidade (em certos casos, o da falsidade). Não é excluída a hipótese metafísica segundo a qual o meu Ego não se comporia de elementos que tivessem existido na realidade (há dez anos ou há um segundo), mas seria apenas constituído por falsas recordações. Este poder do "Génio Maligno" estende-se até aí.

Mas se faz parte da natureza do Ego ser um objeto duvidoso, não se segue que ele seja hipotético. Com efeito, o Ego é a unificação transcendente espontânea dos nossos estados e das nossas ações. A este título, ele não é uma hipótese. Eu não digo: "talvez tenha um Ego", como posso dizer: "talvez odeie Pedro". Eu não procuro, aqui, um sentido unificador dos meus estados. Quando unifico as minhas consciências sob a rubrica "ódio", junto-lhes um certo sentido, qualifico-as. Mas quando incorporo os meus estados na totalidade concreta $E u$ [Moi], não thes junto nada.

É que, com efeito, a relação do Ego com as qualidades, estados e ações não é nem uma relação de emanação (como a relação da consciência com o sentimento) nem uma relação de atualização (como a relação da qualidade 
com o estado). É uma relação de produção poética (no sentido de poiein) ou, se se quiser, de criação.

Cada um, remetendo-se.aos resultados da sua intuição, pode yerificar que o Ego é dado como produzindo os seus estados. Empreendemos aqui uma descrição deste Ego transcendente tal como ele se revela à intuição. Partimos, por conseguinte, deste facto inegável: cada novo estado é religado diretamente (ou indiretamente, pela qualidade) ao Ego como sua origem. Este modo de criação é bem uma criação ex nihilo, no sentido de que o estado não é dado como tendo sido já antes no Eu [Moi]. Mesmo se o ódio se dá como atualização de uma certa potência de rancor ou de ódio, ele permanece como qualquer coisa de novo em relação à potência que atualize. Assim, o ato unificador da reflexão religa, de um modo muito especial, cada novo estado à totalidade concreta do $E u$ [Moi]. Ele não se limita a apreendê-lo como juntando-se a essa totalidade, como fundando-se nela: ele intui uma relação que atravessa o tempo em sentido inverso e que dá o $\mathrm{Eu}$ [Moi] como a fonte do estado. É do mesmo modo, naturalmente, para as ações em relação ao Eu. Quanto às qualidades, se bem que elas qualifiquem o $\mathrm{Eu}[\mathrm{Moi}]$, elas não se dão como sendo qualquer coisa pela qual ele, existiria (como é o caso, por exemplo, para um agregado: cada pedra, cada tijolo existe por ele mesmo e o seu agregado existe por cada um deles). Mas, ao contrário, o Ego mantém as suas qualidades por uma verdadeira criação continuada. No entanto, nós não apreendemos o Ego como sendo, finalmente, uma fonte criadora pura para aquém das suas qualidades. Não nos parece que pudéssemos encontrar, em esqueleto, um pólo, se retirássemos, uma após outra, todas as qualidades. Se o Ego aparece como para lá de cada qualidade ou mesmo de todas, é porque ele é opaco como um objeto: precisaríamos de proceder a um despojamento infinito para retirar todos os seus poderes. E, no termo deste despojamento, não ficaria nada mais, o Ego ter-se-ia desvanecido. O Ego é criador dos seus estados e conserva as suas qualidades na existência por uma espécie de espontaneidade criadora. Não se deverá confundir esta espontaneidade criadora ou conservadora com a responsabilidade, que é um caso especial de produção criadora a partir do Ego. Seria interessante estudar os diversos tipos de processão do Ego relativamente aos seus estados. Trata-se, na maior parte dos casos, de uma processão mágica. Outras vezes, ela pode ser racional (no caso da vontade refletida, por exemplo). Mas sempre com um fundo de ininteligibilidade de que daremos a razão em breve. Com as diferentes consciências (pré-lógicas, infantis, esquizofrénicas, lógicas, etc.), o matiz de criação varia, mas permanece sempre uma produção poética. Um caso muito particular e de interesse considerável é o da psicose de influência. Que quer dizer o doente com estas palavras: "fazem-me ter maus pensamentos"? Tentaremos estudá-lo numa outra obra. Observemos 
no entanto, aqui, que a espontaneidade do Ego não é negada: ela está como que enfeitiçada, mas permanece.

Mas esta espontaneidade não deve ser confundida com a da consciência. Com efeito, o Ego, sendo objeto, é passivo. Trata-se, portanto, de uma pseudo-espontaneidade que encontraria os símbolos apropriados no brotar de uma fonte, de um geiser, etc. Isto é o mesmo que dizer que não se trata senão de uma aparência. A verdadeira espontaneidade deve ser perfeitamente clara: ela $e ́$ o que produz e não pode ser nenhuma outra coisa. Ligada sinteticamente a outra coisa que ela mesma, ela envolveria, com efeito, alguma obscuridade e mesmo uma certa passividade na transformação. Seria preciso, com efeito, admitir uma passagem de si mesmo a outra coisa, o que suporia que a espontaneidade se escapa a ela mesma. A espontaneidade do Ego escapa-se a ela mesma visto que o ódio do Ego, se bem que não podendo existir por si só, possui apesar de tudo uma certa independência em relação ao Ego. De modo que o Ego é sempre ultrapassado pelo que produz, se bem que, de um outro ponto de vista, ele seja o que produz. Daí essas perplexidades clássicas: "como pude $E u$ fazer isto!", "como pude $E u$ odiar meu pai!", etc., etc. Aqui, evidentemente, o todo concreto do eu até hoje intuído sobrecarrega este Eu produtor e mantém-no um pouco em recuo relativamente ao que ele acaba do produzir. O laço entre o Ego e os seus estados permanece, portanto, uma espontaneidade ininteligível. Foi esta espontaneidade que Bergson descreveu em Les données immédiates, é ela que ele toma pela liberdade, sem se aperceber que descreve um objeto, não uma consciência, e que a ligação que estabelece é perfeitamente irracional, porque o produtor é passivo em relação à coisa criada. Por mais irracional que seja, esta relação não deixa menos de ser a que verificamos na intuição do Ego. E vemos o seu sentido: o Ego é um objeto apreendido, mas também constituido pelo saber reflexivo. É um foco virtual de unidade e a consciência constitui-o no sentido inverso ao que a produção real segue: o que é primeiro realmente são as consciências, através das quais se coṇstituem os estados, depois, através destes, o Ego. Mas como a ordem é invertida por uma consciência que se aprisiona no mundo para fugir de si, as consciências são dadas como emanando dos estados e os estados como produzidos pelo Ego. Segue-se que a consciência projeta a sua própria espontaneidade sobre o objeto Ego para lhe conferir o poder criador que lhe é absolutamente necessário. Só que esta espontaneidade, representada e hipostasiada num objeto, toma-se uma espontaneidade bastarda e degradada, que conserva magicamente o seu poder criador tomando-se ao mesmo tempo passiva. Daí a irracionalidade profunda da noção de Ego. Conhecemos outros aspetos degradados da espontaneidade consciente. Citarei apenas um: uma mímica expressiva e apurada pode dar-nos a "Erlebnis" do nosso interlocutor com todo o seu sentido, todos os seus matizes, toda a sua frescura. Mas ela 
dá-no-la degradada, quer dizer, passiva. Estamos, assim, cercados de objetos mágicos, que conservam como que uma lembrança da espontaneidade da consciência sendo ao mesmo tempo objetos do mundo. Eis por que o homem é sempre um feiticeiro para o homem. Com efeito, esta ligação poética de duas passividades, das quais uma cria a outra espontaneamente, é a própria base da feitiçaria, é o sentido profundo da "participação". Eis por que, também; somos nós para nós mesmos feiticeiros de cada vez que consideramos a nosso $\mathrm{Eu}[\mathrm{Moi}]$.

Em virtude desta passividade, o Ego é suscetível de ser afetado. Nada pode agir sobre a consciência, porque ela é causa de si. Mas, ao contrário, o Ego que produz sofre o choque do retomo daquilo que produz. Ele está "comprometido" com o que produz. Há aqui uma inversão de relação: a ação ou o estado voltam-se para o Ego para o qualificarem. Isto traz-nos de volta ainda à relação de participação. Todo e qualquer novo estado produzido pelo Ego tinge e matiza o Ego no momento em que o Ego o produz. O Ego está, de algum modo, enfeitiçado por esta ação, participa nela. Não é o crime cometido par Raskolnikoff que se incorpora no seu Ego. Ou antes, para ser exato, é o crime, mas sob uma forma condensada, sob a forma de uma contusão. Assim, tudo que o Ego produz impressiona-o; é preciso acrescentar: $e$ somente o que ele produz. Poder-se-ia objetar que o Eu [Moi] pode ser transformado por acontecimentos exteriores (ruína, luto, deceções, mudança de meio social, etc.). Mas só enquanto eles são para ele a ocasião de estados ou de ações. Tudo se passa como se o Ego estivesse protegido, pela sua espontaneidade fantasmática, de qualquer contacto direto com o exterior, como se ele não pudesse comunicar com o Mundo a não ser por intermédio dos estados e das ações. É visível a razão deste isolamento: é, muito simplesmente, porque o Ego é um objeto que não aparece senão à reflexão e que, por esse facto, está radicalmente cortado do mundo. Ele não vive no mesmo plano.

Do mesmo modo que o Ego é uma síntese irracional de atividade e de passividade, ele é também síntese de interịoridade e de transcendência. Ėle é, num certo sentido, mais "interior" à consciência que os estados. É, precisamente, a interioridade da consciência refletida contemplada pela consciência reflexiva. Mas é fácil de compreender que a reflexão, contemplando a interioridade, faz dela um objeto posto diante dela. Que entendemos nós, com efeito, por interioridade? Simplesmente que, para a consciência, ser e conhecer-se são uma só e mesma coisa. Coisa que se pode exprimir de várias maneiras: posso dizer, por exemplo, que, para a consciência, a aparência é o absoluto enquanto ela é aparência ou ainda que a consciência é um ser cuja essência implica a existência. Estas diferentes fórmulas permitem-nos concluir que se vive a interioridade (que se "existe interiormente"), mas que não se a contempla, visto que ela estaria ela mesma para lá da contemplação, como sua condição. 
Não serviria para nada objetar que a reflexão põe a consciência refletida e, com isso, a sua interioridade. O cașo é específico: reflexão e refletido não fazem senão um, como o mostrou muito bem Husserl, e a interioridade de uma funde-se na do outro. Mas pôr diante de si a interioridade é, forçosamente, tomá-la pesada ao modo de um objeto. É como se ela se fechasse sobre si e não nos oferecesse senão os seus exteriores; como se fosse preciso "andar a sua volta" para a compreender. E é mesmo assim que o Ego se dá à reflexão: como uma interioridade fechada sobre ela mesma. Ele é interior para ele, não para a consciência. Naturalmente, trata-se ainda de um complexo contraditório: com efeito, uma interioridade não tem nunca exterior. Ela não pode ser concebida senão por ela mesma e é por isso que não podemos apreender as consciências de outrem (apenas por isso e não porque as corpos nos separam). $\mathrm{Na}$ realidade, esta interioridade degradada e irracional deixa-se analisar em duas estruturas muito particulares: a intimidade e a indistinção. Em relação à consciência, o Ego dá-se como íntimo. Tudo se passa como se o Ego fosse $d a$ consciência, apenas com esta diferença essencial de ele ser opaco para a consciência. E esta opacidade é apreendida como indistinção. A indistinção, de que se faz, sob diversas formas, um use frequente na filosofia, é a interioridade vista do exterior ou, se se prefere, a projeção degradada da interioridade. É esta indistinção que se encontraria, por exemplo, na famosa "multiplicidade de interpenetração" de Bergson. É ainda esta indistinção, anterior às especificações da natureza naturada, que se encontra no-Deus de numerosos místicos. Pode-se compreendê-la ora como uma indiferenciação primitiva de todas as qualidades ora como uma forma pura do ser, anterior a toda qualificação. Estas duas formas de indistinção pertencem ao Ego, segundo o modo como ele é considerado. $\mathrm{Na}$ espera, por exemplo - (ou quando Marcel Arland explica que é preciso um acontecimento extraordinário para revelar o Eu [Moi] verdadeiro) -, o Ego dá-se como uma potência nua, que se precisará e se cristalizará no contacto com os acontecimentos. ${ }^{8}$ Ao contrário, depois da ação, parece quo o Ego reabsorve o ato praticado numa multiplicidade de interpenetração. Nos dois casos, trata-se de totalidade concreta, mas a síntese totalitária é operada com intenções diferentes. Talvez que se pudesse chegar a dizer que o Ego, em relação ao passado, e multiplicidade de interpenetração e, em relação ao futuro, potência nua. Mas devemos desconfiar aqui de uma excessiva esquematização.

Tal qual é, o Eu [Moi] permanece-nos desconhecido. E isso pode compreender-se facilmente: ele dá-se como um objeto. Portanto, o único método para o conhecer é a observação, a aproximação, a espera, a experiência.

${ }^{8}$ Como no caso em que alguém com um comportamento passional, querendo dar a entender que não sabe até onde a paixão o levará, diz: "tenho medo de mim". 
Mas estes procedimentos, que se adequam perfeitamente a todo transcendente não-íntimo, não se adequam aqui, devido ao facto da própria intimidade do $\mathrm{Eu}$ [Moi]. Ele está demasiado presente para que nos possamos pôr, a seu respeito, de um ponto de vista verdadeiramente exterior. Se recuamos para ganhar. distância, ele acompanha-nos nesse recuo. Ele está infinitamente próximo e não posso contorná-lo. Serei eu preguiçoso ou trabalhador? Decidirei, sem dúvida, se me dirigir àqueles que me conhecem e lhes perguntar a sua opinião. Ou posso ainda colecionar os factos que me dizem respeito e tentar interpretá-los tão objetivamente como se se tratasse de um outro. Mas seria inútil dirigir-me diretamente ao Eu [Moi] e tentar beneficiar da sua intimidade para o conhecer. Pois é ela, ao contrário, que nos barra o caminho. Assim, "conhecer-se bem" é, fatalmente, tomar sobre si o ponto de vista de outrem, quer dizer, um ponto de vista forçosamente falso. $E$ todos os que tentaram conhecer-se concordarão, esta tentativa de introspeção apresenta-se, desde a origem, como o esforço para reconstituir, com peças desligadas, com fragmentos isolados, o que se deu originariamente de uma vez, de um só lance. Assim, a intuição do Ego é uma miragem perpetuamente falaz, pois ela ao mesmo tempo dá tudo e não dá nada. Como poderia ser de outro modo, aliás, visto que o Ego não é a totalidade real das consciências (esta totalidade seria contraditória, como todo infinito em ato), mas a unidade ịdeal de todos os estados e ações. Sendo ideal, esta unidade pode, naturalmente, abarcar uma infinidade de estados. Mas percebe-se bem que o que é dado à intuição concreta e plena é somente esta unidade enquanto se incorpora no estado presente. A partir deste núcleo concreto, uma quantidade maior ou menor de intenções vazias (em direito, uma infinidade) dirigem-se para o passado e para o futuro, e visam os estados e as ações que não estão dados presentemente. Os que têm algum conhecimento da fenomenologia compreenderão sem dificuldade que o Ego seja ao mesmo tempo uma unidade ideal de estados, cuja maioria está ausente, e uma totalidade concreta que se dá por inteiro à intuição: isso significa simplesmente que o Ego é uma unidade noemática e não noética. Uma árvore, ou uma cadeira, não existem de outro modo. Naturalmente, as intenções vazias podem sempre ser preenchidas e um qualquer estado, uma qualquer ação pode sempre reaparecer à consciência como sendo ou tendo sido produzida pelo Ego.

Enfim, o que impede radicalmente que se adquira reais conhecimentos sobre o Ego é o modo muito especial como ele se dá à consciência reflexiva. Com efeito, o Ego só aparece quando não o olhamos. É preciso que o olhar reflexivo se fixe na "Erlebnis", enquanto ela emana do estado. Então, por detrás do estado, no horizonte, aparece o Ego. Ele não é nunca visto senão pelo canto do olho. Assim que volto o meu olhar para ele e que quero atingi-lo sem passar pela "Erlebnis" e o estado, ele dissipa-se. É que, com efeito, ao procurar apreender o Ego por ele mesmo e como objeto direto da minha cons- 
ciência, recaio no plano irrefletido e o Ego desaparece com o ato reflexivo. Daí essa impressão de incerteza irritante que muitos filósofos traduzem ao pôr o Eu para aquém do estado de consciência e ao afirmarem que a consciência deve voltar-se sobre ela mesma para aperceber o Eu que está por detrás dela. Não é nada disso, mas por natureza o Ego é fugidio.

É certo, no entanto, que o Eu aparece no plano irrefletido. Se me perguntam "que fazes tu?" e respondo, atarefado, "tento pendurar este quadro" ou "conserto o pneu de trás", estas frases não nos transportam para o plano da reflexão, pronuncio-as sem parar de trabalhar, sem parar de considerar unicamente ạs ações, enquanto elas estão feitas ou são a fazer, não enquanto eu as faço. Mas este "Eu" de que é aqui questão não é, contudo, uma simples forma sintática. Ele tem um sentido; é muito simplesmente um conceito vazio e destinado a permanecer vazio. Do mesmo modo que posso pensar numa cadeira na ausência de qualquer cadeira e pelo simples conceito, posso pensar o Eu ná ausência do Eu. É isso que toma evidente a considerarão de frases tais como: "que fazes esta tarde?", "vou ao escritório" ou "encontrei o meu amigo Pedro" ou "tenho de lhe escrever", etc., etc. Mas o Eu, ao cair do plano refletido no plano irrefletido, não se esvazia simplesmente. Ele degrada-se: perde a sua intimidade. O conceito não poderia nunca ser preenchido pelos dados da intuição, pois ele visa, agora, outra coisa que eles. O Eu que encontramos aqui é, de algum modo, o suporte das ações que (eu) faço ou devo fazer no mundo, enquanto elas são qualidades do mundo e não unidades de consciências. Por exemplo: a madeira deve ser partida em pequenos pedaços para que o lume acenda. Deve: é uma qualidade da madeira e uma relação objetiva da madeira com o fogo que deve ser aceso. Neste momento, eu parto a madeira, o que quer dizer que a ação se realiza no mundo e que o suporte objetivo e vazio desta ação é o eu-conceito. Eis por que razão o corpo e as imagens do corpo podem consumar a degradação total do Eu concreto da reflexão no Eu-conceito, ao servirem a este de preenchimento ilusório. Digo "Eu", parto a madeira e vejo e sinto o objeto "corpo" em vias de partir a madeira. O corpo serve então de símbolo visível e tangível para o Eu. Vê-se, portanto, a série de refrações e de degradações de que uma "egologia" se deveria ocupar.

$$
\begin{aligned}
& \text { Plano refletido }\left\{\begin{array}{l}
\text { Consciência refletida - imanência - interioridade } \\
\text { Ego intuitivo - transcendência-intimidade } \\
\text { (domínio do psíquico) }
\end{array}\right. \\
& \text { Plano irrefletido }\left\{\begin{array}{l}
\text { Eu-conceito (facultativo) - vazio transcendente - sem "intimidade" } \\
\text { Corpo como preenchimento ilusório do Eu-conceito } \\
\text { (domínio do psicofisico) }
\end{array}\right.
\end{aligned}
$$




\section{E) O EUE A CONSCIÊNCIA NO COGITO}

Poder-se-ia perguntar por que razão o Eu aparece por ocasião do Cogito, visto que o Cogito, se é corretamente executado, é apreensão de uma consciência pura, sem constituição de estado nem de ação. Para dizer a verdade, o Eu não é necessário aqui, já que ele não é nunca unidade direta das consciências. Pode mesmo supor-se uma consciência executando um ato reflexivo puro que a daria a ela mesma como uma espontaneidade não-pessoal. Só que é preciso considerar que a redução fenomenológica não é nunca perfeita. Intervém aqui um grande número de motivações psicológicas. Quando Descartes executa o Cogito, ele efetua-o em ligação com a dúvida metódica, com a ambição de "fazer avançar as ciências", etc., coisas que são ações e estados. Assim, o método cartesiano, a dúvida, etc., dão-se por natureza como empreendimentos de um Eu. É totalmente natural que o Cogito, que aparece no termo destes empreendimentos e que se dá como logicamente ligado à dúvida metódica, veja aparecer um Eu no seu horizonte. Este Eu é uma forma de ligação ideal, uma maneira de afirmar que o Cogito é verdadeiramente tomado na mesma forma que a dúvida. Numa palavra, o Cogito é impuro; é uma consciência espontânea, sem dúvida, mas que permanece sinteticamente ligada a consciências de estados e de ações. A prova disso é que o Cogito se dá ao mesmo tempo como o resultado lógico da dúvida e como o que lhe põe fim. Uma apreensão reflexiva da consciência espontânea como espontaneidade não-pessoal exigiria ser consumada sem nenhuma motivação anterior. Ela é sempre possível de direito, mas permanece deveras improvável ou, pelo menos, extremamente rara na nossa condição de homens. De todo modo, como dissemọ mais acima, o. Eu que aparece no horizonte do "Eu penso" não se dá como produtor da espontaneidade consciente. A consciência produz-se em face dele e vai para ele, vai juntar-se-lhe. É tudo o que se pode dizer.

\section{CONCLUSÃO}

Queremos, em conclusão, apresentar apenas as três observações seguintes:

1. $\left.{ }^{\circ}\right)$ A conceção do Ego que propomos parece-nos realizar a libertação do campo transcendental e, ao mesmo tempo, a sua purificação.

O campo transcendental, purificado de qualquer estrutura egológica, readquire a sua limpidez primeira. Num sentido, é um nada, visto que todos os objetos físicos, psicofísicos e psíquicos, todas as verdades, todos os valores estão fora dele, visto que o meu Eu [Moi] deixou, ele mesmo, de fazer parte dele. Mas este nada é $t u d o$, visto que ele é consciência de todos esses objetos. 
Já não é questão de "vida interior", no sentido em que Brunschvicg opõe "vida interior" e "vida espiritual", porque já não há nada que seja objeto e que possa ao mesmo tempo pertencer a intimidade da consciência: As dúvidas, os remorsos, as pretensas "crises de consciência", etc. - numa palavra, toda a matéria dos diários íntimos - tomam-se simples representações. E talvez que se pudesse tirar daí alguns sãos preceitos de discrição moral. Mas, além disso, é preciso notar que, deste ponto de vista, o meu próprio Ego, deixa de ser minha propriedade exclusiva. Mais precisamente: até aqui fazia-se uma distinção radical entre a objetividade de uma coisa espácio-temporal ou de uma verdade eterna e a subjetividade dos "estados" psíquicos. Parecia que o sujeito detinha uma posição privilegiada em relação aos seus próprios estados. Segundo esta conceção, quando dois homens falam de uma mesma cadeira, eles falam certamente de uma mesma coisa, esta cadeira que pegamos e levantamos é a mesma que a que o outro vê, não há simples correspondência de imagens, há um só objeto. Mas parecia que, quando Paulo tenta compreender um estado psíquico de Pedro, ele não podia atingir este estado, cuja apreensão intuitiva pertencia apenas a Pedro. Ele não podia senão tomar em vista um equivalente, criar conceitos vazios que tentavam em vão atingir uma realidade por essência subtraída à intuição. A compreensão psicológica fazia-se por analogia. A fenomenologia veio ensinar-nos que os estados são objetos, que um sentimento enquanto tal (um amor ou um ódio) é um objeto transcendente que não poderia contrair-se na unidade de interioridade de uma "consciência". Por conseguinte, se Pedro e Paulo falam ambos do amor de Pedro, por exemplo, não é mais verdade que um fale cegamente e por analogia do que o outro apreende em pleno. Eles falam da mesma coisa; eles apreendem-na, sem dúvida, através de processos diferentes, mas estes podem ser ambos igualmente intuitivos. E o sentimento de Pedro não é mais certo para Pedro do que para Paulo. Ele pertence, tanto para um como para outro, à categoria dos objetos que se podem pôr em dúvida. Mas toda esta conceção profunda e nova fica comprometida se o Eu [Moi] que odeia ou ama, permanece uma estrutura essencial da consciência. O sentimento, com efeito, permanece-lhe ligado. Esse sentimento "cola-se" ao Eu [Moi]. Se se puxa o Eu [Moi] para a consciência, puxa-se com ele o sentimento. Tornou-se visível para nós, pelo contrário, que o Eu [Moi] era um objeto transcendente, como o estado, e que, por esse facto, era acessivel a dois tipos de intuição: uma apreensão intuitiva pela consciência de que ele é o Eu [Moi], uma apreensão, menos clara mas não menos intuitiva, por outras consciências. Numa palavra, o Eu [Moi] de Pedro é acessível tanto à minha ịntuição como à de Pedro e, nos dois casos, ele é objeto de uma evidência inadequada. Se é assim, em Pedro nada mais resta de "impenetrável" a não ser a sua consciência mesma: Mas esta é-o radicalmente. Queremos dizer que ela não é apenas refratária à intuição, mas também ao 
pensamento. Eu não posso conceber a consciência de Pedro sem fazer dela um objeto (já que eu não a concebo como sendo minha consciência). Não posso concebê-la porque seria preciso pensá-lạ como interioridade pura e, ao mesmo tempo, como transcendência, o que é impossível. Uma consciência não pode conceber outra consciência que ela mesma. Assim, podemos distinguir, graças à nossa conceção do Eu [Moi], uma esfera acessível à psicologia, na qual o método de observação externa e a método introspetivo têm os mesmos direitos e podem ajudar-se mutuamente, e uma esfera transcendental pura, acessível apenas à fenomenologia.

Esta esfera transcendental é uma esfera de existência absoluta, quer dizer, de espontaneidades puras, que não são nunca objetos e que se determinam por elas mesmas a existir. Sendo o Eu [Moi] objeto, é evidente que nunca poderia dizer: a minha consciência, quer dizer, a consciência do meu $E u$ [Moi] (salvo num sentido puramente designativo, como por exemplo se diz: o dia do meu batizado). O Ego não é proprietário da consciência, ele é o objeto. Certamente que nós constituímos espontaneamente os nossos estados e as nossas ações como produções do Ego. Mas os nossos estados e as nossas ações são também objetos. Não temos nunca intuição direta da espontaneidade de uma consciência instantânea como produto do Ego. Tál seria impossível. É apenas no plano das significações e das hipótèses psicológicas que podemos conceber semelhante produção, - e este erro não é possível senão porque, neste plano, o Ego e a consciência estão no vazio. Neste sentido, se se compreende o "Eu penso" de modo a fazer do pensamento uma produção do Eu, então o pensamento foi já constituído como passividade e estado, quer dizer, como objeto; abandonou-se o plano da reflexão pura, na qual o. Ego aparece sem dúvida, mas no horizonte da espontaneidade. A atitude reflexiva é corretamente expressa nesta famosa frase de Rimbaud (na carta do vidente) "Eu é um outro". O contexto prova que ele quis dizer simplesmente que a espontaneidade das consciências não poderia emanar do Eu, ela vai para o Eu, alcança-o, deixa-o entrever-se sob a sua límpida espessura, mas ela dá-se antes de tudo como espontaneidade individuada e impessoal. A tese, comummente aceite, segundo a qual os nossos pensamentos brotariam de um inconsciente impessoal e se "personalizariam" ao se tomarem conscientes, parece-nos ser uma interpretação grosseira e materialista de uma intuição correta. Ela foi sustentada por psicólogos que compreenderam muito bem que a consciência não "saía" do Eu, mas que não podiam aceitar a ideia de uma espontaneidade que se produzisse a si mesma. Estes psicólogos imaginaram ingenuamente, por conseguinte, que as consciências espontâneas "saíam" do inconsciente onde existiam já, sem se aperceberem que eles apenas tinham feito recuar o problema da existência, que é preciso acabar mesmo por formular, e que o tinham 
obscurecido, já que a existência anterior das espontaneidades nos limites pré-conscientes seria necessariamente uma experiência passiva.

Podemos, portanto, formular a nossa tese: a consciência transcendental é uma espontaneidade impessoal. A cada instante, ela determina-se à existência sem que se possa conceber qualquer coisa antes dela. Assim, cada instante da nossa vida consciente revela-nos uma criação ex nihilo. Não um arranjo novo, mas uma nova existência. Há qualquer coisa angustiante para cada um de nós ao apreender ao vivo esta criação incansável de existência de que nós não somos criadores. Neste plano, o homem tem a impressão de se escapar incessantemente, de se extravasar, de se surpreender com uma riqueza sempre inesperada e é novamente ao inconsciente que ele incumbe de dar razão desta ultrapassagem do Eu [Moi] pela consciência. O Eu [Moi] não tem nenhum domínio sobre esta espontaneidade, pois a vontade é um objeto que se constitui para e por esta espontaneidade. A vontade dirige-se para os estados, para os sentimentos ou para as coisas, mas ela não se volta nunca para a consciência. Damos conta disso naqueles casos em que se tenta querer uma consciência (quero adormecer, não quero pensar mais nisso, etc.). Nestes diferentes casos, é necessário por essência que a vontade seja conservada e mantida pela consciência radicalmente oposta ao que ela quereria ver nascer (se quero adormecer, permaneço acordado, - se não quero pensar em tal ou tal coisa, penso precisamente por isso). Parece-nos que esta espontaneidade monstruosa está na origem de numerosas psicastenias. A consciência assusta-se com a sua própria espontaneidade, porque ela sente-a como para lá da liberdade. É o que se pode ver claramente num exemplo de Janet. Uma jovem casada tinha medo de, quando o seu marido a deixava só, se pôr à janela e interpelar os transeuntes à maneira das prostitutas. Nada na sua educação, no seu passado nem no seu carácter pode servir de explicação para semelhante temor. $O$ que nos parece é que, muito simplesmente, uma circunstância sem importância (leitura, conversação, etc.) tinha determinado nela o que se poderia chamar uma vertigem da possibilidade. Ela descobria-se como monstruosamente livre e esta liberdade vertiginosa aparecia-lhe por ocasião desse gesto que tinha medo de fazer. Mas esta vertigem só é compreensível se a consciência aparece de súbito a ela mesma como extravasando infinitamente nas suas possibilidades o Eu que the serve ordinariamente de unidade.

Talvez, com efeito, que a função essencial do Ego não seja tanto teórica como prática. Nós sublinhámos, com efeito, que ele não encerra a unidade dos fenómenos, que ele se limita a refletir uma unidade ideal, ao passo que a unidade concreta e real está executada desde há muito. Mas talvez que o seu papel essencial seja encobrir à consciência a sua própria espontaneidade. Uma descrição fenomenológica da espontaneidade mostraria, com efeito, que esta toma impossível toda e qualquer distinção entre ação e paixão e toda e qual- 
quer conceção a respeito de uma autonomia da vontade. Estas noções só têm significação sobre um plano em que toda atividade se dá como emanando de uma passividade que ela transcende, numa palavra, sobre um plano em que o homem se considera ao mesmo tempo como sujeito e como objeto. É uma necessidade eidética, porém, que se não possa distinguir entre espontaneidade voluntária e espontaneidade involuntária.

Tudo se passa como se a consciência constituísse o Ego como uma falsa representação dela mesma, como se ela se hipnotizasse com este Ego que ela constituiu, se absorvesse nele, como se ela dele fizesse a sua salvaguarda e a sua lei: é graças ao Ego, com efeito, que se poderá efetuar uma distinção entre o possível e o real, entre a aparência e o ser, entre o querido e o sofrido.

Mas pode acontecer que a consciência, subitamente, se apresente no plano reflexivo puro. Não talvez sem $E g o$, mas como escapando por todos os lados ao Ego, como dominando-o e sustentando-o fora dela por uma criação continuada. Neste plano, ja não há distinção entre o possível e o real, visto que a aparência é o absoluto. Já não há barreiras, limites, nada mais que dissimule a consciência de si mesma. Então a consciência, apercebendo-se do que poderíamos designar como a fatalidade da sua espontaneidade, angustia-se repentinamente: é esta angústia absoluta e irremediável, este medo de si, que nos parece constitutivo da consciência pura e é ele que dá a chave da perturbação psicasténica de que falamos. Se o Eu do Eu penso é a estrutura primeira da consciência, esta angústia é impossível. Se, pelo contrário, se adota o nosso ponto de vista, não só temos uma explicação coerente desta perturbação como temos ainda um motivo permanente para efetuar a redução fenomenológica. É sabido que Fink confessa não sem melancolia, no seu artigo dos Kantstudien, que tanto quanto se permaneça na atitude "natural", não há razão, não há "motivo" para praticar a epoché. Com efeito, esta atitude natural é perfeitamente coerente e não se poderia encontrar nela essas contradições que, segundo Platão, conduzem o filósofó a efetuar uma conversão filosófica. Assim, na fenomenologia de Husserl, a epoché aparece como um milagre. O próprio Husserl, nas Meditações Cartesianas, alude de modo muito vago a certos motivos psicológicos que levariam a efetuar a redução. Mas esses motivos não parecem em nada suficientes e, sobretudo, a redução não parece poder efetuar-se senão no termo de um longo estudio; ela aparece, portanto, como uma operação douta, o que lhe confere uma espécie de gratuitidade. Ao contrário, se a "atitude natural" aparece por inteiro como um esforço que a consciência faz para escapar a ela mesma, projetando-se no Eu [Moi] e absorvendo-se nele, e se este esforço não é nunca completamente recompensado, se é suficiente um ato de simples reflexão para que a espontaneidade consciente se arranque bruscamente do Eu e se dê como independente, a epoché já não é um milagre, já não é um método intelectual, um procedimento douto: é uma 
angústia que se nos impõe e que não podemos evitar, é ao mesmo tempo um acontecimento puro de origem transcendental e um acidente sempre possível da nossa vida quotidiana.

$2^{\circ} .^{\circ}$ Esta conceção do Ego parece-nos ser a única refutação possível do solipsismo. A refutação que Husserl apresenta em Formale und Transzendentale Logik e nas Meditações Cartesianas não nos parece poder atingir um solipsista determinado e inteligente. Enquanto o Eu permanecer uma estrutura da consciência, será sempre possível opor a consciência com o seu Eu a todos os outros existentes. No fundo, sou mesmo $\mathrm{Eu}$ [Moi] que produzo o mundo: Pouco importa que certos estratos desse mundo necessitem, devido à sua própria natureza, de uma relação a outrem. Esta relação pode ser uma simples qualidade do mundo que eu crio e não me obriga de modo nenhum a aceitar a existência real de outros Eus.

Mas se o Eu se toma um transcendente, então ele participa em todas as vicissitudes do mundo. Ele não é um absoluto, ele não criou o universo, ele fica, como todas as outras existências, ao alcance da epoché; e o solipsismo toma-se impensável desde o momento em que o Eu já. não tem uma posição privilegiada. Com efeito, em vez de se formular: "Só eu existo como absoluto", deveria enunciar-se: "Só a consciência absoluta existe como absoluta", coisa que é, evidentemente, um truísmo. O meu Eu, com efeito, nã̃o é mais certo para a consciência que o Eu dos outros homens. Ele é apenas mais íntimo.

$\left.3 .^{\circ}\right)$ Os teóricos de extrema-esquerda acusaram algumas vezes a fenomenologia de ser um idealismo e de afogar a realidade na torrente das ideias. Mas se o idealismo é a filosofia sem mal de Brunschvicg, se ele é uma filosofia em que o esforço de assimilação espiritual não encontra nunca resistências exteriores, onde o sofrimento, a fome, a guerra se diluem num lento processo de unificação das ideias, nada é mais injusto que chamar idealistas aos fenomenólogos. Pelo contrário, há séculos que não se fazia sentir na filosofia uma corrente tão realista. Eles voltaram a mergulhar o homem no mundo, deram todo o seu peso às suas angústias e aos seus sofrimentos, às suas revoltas também. Infelizmente, enquanto o Eu permanecer uma estrutura da consciência absoluta, poder-se-á acusar ainda a fenomenologia de ser uma "doutrina-refúgio", de atirar ainda uma parcela do homem para fora do mundo e de afastar com isso a atenção dos verdadeiros problemas. Não nos parece que essa acusação tenha razão de ser se se faz do Eu [Moi] um existente rigorosamente contemporâneo do mundo e cuja existência tem as mesmas características essenciais que o mundo. Sempre me pareceu que uma hipótese de trabalho tão fecunda como o materialismo histórico não exigia de modo nenhum como fundamento essa absurdidade que é o materialismo metafísico. Não é, com efeito, neces- 
sário que o objeto preceda $o$ sujeito para que os pseudovalores espirituais se dissipem e para que a moral reencontre as suas bases na realidade. Basta que o Eu [Moi] seja contemporâneo do mundo e que a dualidade sujeito-objeto, que é puramente lógica, desapareça definitivamente das preocupações filosóficas. O Mundo não criou o Eu [Moi], o Eu [Moi] não criou o Mundo, eles são dois objetos para a consciência absoluta, impessoal, e é por ela que eles estão ligados. Esta consciência absoluta, quando é purificada do Eu, nada mais tẹm que seja característico de um sujeito, nem é também uma coleção de representações: ela é muito simplesmente uma condição primeira e uma fonte absoluta de existência. E a relaçã́o de interdependência que ela estabelece entre o Eu [Moi] e o Mundo basta para que o Eu [Moi] a pareça como "em perigo" diante do Mundo, para que o Eu [Moi] (indiretamente e por intermédio dos estados) retire do Mundo todo o seu conteúdo. Nada mais é preciso para fundamentar filosoficamente uma moral e uma política absolutamente positivas.

Tradução

Pedro M. S. Alves 